\title{
On the concept of Total Institution
}

\author{
Sandro Serpa ${ }^{1}$ \\ ${ }^{1}$ University of the Azores, Faculty of Social and Human Sciences, Department of Sociology; Interdisciplinary Centre of \\ Social Sciences -CICS.UAc/CICS.NOVA.UAc, and Interdisciplinary Centre for Childhood and Adolescence -NICA - \\ UAc, Ponta Delgada, Portugal
}

Correspondence: Sandro Serpa, University of the Azores, Faculty of Social and Human Sciences, Department of Sociology, Ponta Delgada, Azores, Portugal. sandro.nf.serpa@uac.pt

Received: July 23, 2018

doi:10.11114/ijsss.v6i9.3467
Accepted: August 1, $2018 \quad$ Available online: August 20, 2018

URL: https://doi.org/10.11114/ijsss.v6i9.3467

\begin{abstract}
This conceptual paper puts forward Goffman's concept of total institution, a classic of sociology. It is concluded that this concept holds heuristic capacity, notwithstanding the great constraint of the action of its members, which, however, does not determine each actor's margins of freedom, at least in the study carried out. Even in extreme situations, organisational actors discover or create spaces of (some) autonomy, in which they exercise their (even if highly regulated) freedom beyond the structure of the organisation, a fact that is acknowledged by Goffman himself.
\end{abstract}

Keywords: total institution, autonomy of actors, Goffman

\section{Introduction}

The level of closure of an organisation is a topic that has long been a concern for researchers. This conceptual paper puts forward Goffman's concept total institution, a classic of sociology. For this purpose, a discussion is presented on its definition and the features of total institution, as well as the situation of actors' individual freedom.

\section{On the Total Institution}

There are social organisations that display specific internal rules in the sense of a certain physical (spatial) and/or social isolation, through which controlled monitoring is exercised, in a division between those who are controlled and those who supervise (with the possibility of internal differences in each of these groups).

A good example of the most extreme situations of self-closure is Goffman's (2007) analysis of total institutions as a "social hybrid, part residential community, part formal organization" (p. 22), which is defined as "a place of residence and work where a large number of like-situated individuals cut off from the wider society for an appreciable period of time together lead an enclosed and formally administered round of life" (p. 11). Among these, the author mentions, as examples, asylums, prisons, convents, concentration camps and boarding schools.

According to Goffman (2007), the total institution has the following features:

First, all aspects of life are conducted in the same place and under the same single authority. Second, each phase of the member's daily activity is carried out in the immediate company of a large batch of others, all of whom are treated alike and required to do the same thing together. Third, all phases of day's activities are

${ }^{1}$ This article is a version of the Portuguese paper: Serpa, S. (2014). O contributo do conceito de instituição total para uma leitura empírica de um contexto educativo [The contribution of the concept of total institution to an empirical reading of an educational context]. Atas do VIII Congresso Português de Sociologia [Proceedings of the VIII Portuguese Congress of Sociology]. Lisbon: Portuguese Sociology Association. Retrieved from http://www.aps.pt/viii_congresso/VIII_ACTAS/VIII_COM0101.pdf, presented in the Sociology of Education Section, Table: Educational paths: integration or social segregation?, at the VIII Congresso Português de Sociologia - 40 anos de democracia(s): progressos, contradições e prospetivas [VIII Portuguese Congress of Sociology - 40 years of democracy(ies): progress, contradictions and prospects], organised by the Portuguese Sociology Association, April 14-16, 2014, in Évora, at the University of Évora (April 15, 2014). We thank the participants for their valuable comments on this presentation, which helped to enrich this paper. 
tightly scheduled, with one activity leading at prearranged time into the next, the whole sequence of activities being imposed from above by a system of explicit formal rulings and a body of officials. Finally, the various enforced activities are brought together into a single rational plan purportedly designed to fulfil the official aim of the institution (pp. 17-18).

Furthermore, Goffman (1999) adds two particularities to these features:

[...] these institutions have what can be called a culture of imposition, in the sense that those who enter it already belong to their own cultures. These recruits are already fully shaped, in social and cultural terms. Since then, everything built within the institution must be imposed, in some way, on what already exists. [...] these institutions often seem to engender a kind of counter-vision of the world, an ideology or perspective of the world that places the inmate outside of it (p. 121).

In the situation of children's and young people's boarding childcare, this dimension of cultural tension is revealed with intensity when it comes to young people admitted for already having a culture attained through a previous socialisation, which leads Goffman (2007), explicitly, to "exclude orphanages and children's homes from the list of total institutions" (p. 23).

Nevertheless, it seems appropriate for us to consider, for example, that boarding organisations for children and young people can be confronted, to some extent, for analytical purposes, with the total institution - as a social unit that takes in children and young people, in a boarding system, in which students cohabit in a common residence, where they sleep, play and work in the same place that responds to their needs (Goffman, 2007), considering that the presence of both young people sheltered and adult employees, both with already defined external cultural references, can generate tensions, both in themselves and in those with whom they interact.

\section{Final Remarks}

No organisational socialisation generates a full consonance. Factors such as the functions performed, the personal, organisational and social trajectory, the rules and norms in force, the power relations that are established, as well as the type of negative or positive sanctions are elements that, among others, influence the level of conformity and the intensity with which this socialisation is internalised by the members of an organisation through formal and/or informal processes.

It is reasonable, thus, to conclude that organisational socialisation does not determine each actor's margins of freedom. Even in extreme situations, organisational actors discover or create spaces of (some) autonomy, in which they exercise their (even if much regulated) freedom beyond the structure of the organisation. A good example of this is Goffman's (2007) analysis of total institutions, in which the author demonstrates that even in extreme situations, such as life in asylums, prisons, monasteries, concentration camps or boarding schools, assimilation is never total.

In these socialisations, there are always margins for each one's autonomy, considering that "the socialisation process has itself an interactive nature. [...] One socialises at the same time that one is socialised, one builds oneself up to the extent that one is built by others" (Javeau, 1998, pp. 166-167), in a process that is always renewed in each situation. Hence, socialisation in the organisation is never total, considering at least two sets of factors: socialisation is an active adjustment of the subject, thus permanent, and, on the other hand, it is a process that never happens in an exactly identical way for different individuals and times.

Even in situations such as those of total institution (Goffman, 2007) there is freedom, there is always room for some indeterminacy. These "margins of relative autonomy" (Lima, 1998, p. 582) that actors have allow them to exercise their relative autonomy in a close connection with the more or less conscious reading that they make of the situation, and that is conditioned by the external and internal socialisation of the organisation and by their motivation. In any empirical analysis, the actors' spaces of freedom, whether individual or collective, must be considered in their relative autonomy.

As already acknowledged by Goffman (2007), on the one hand, "the institution is not an entirely isolated world" (p. 92); there is always some form of relationship with the external environment. On the other hand, the actors reveal that they have a space of autonomy, inasmuch that "we find that participants refuse, to some extent, to accept the official interpretation of what they should give and take from the organisation and, moreover, as to the type of self and world that they must accept for themselves. [...] [there] is a movement of freedom. Whenever worlds are imposed, underworlds are created" (p. 246).

\section{Acknowledgments}

University of Azores, Interdisciplinary Centre of Social Sciences - CICS.UAc/CICS.NOVA.UAc, UID/SOC/04647/2013, with the financial support of FCT/MEC through national funds and when applicable co-financed by FEDER under the PT2020 Partnership Agreement. 


\section{References}

Goffman, E. (1999). Os momentos e os seus homens [The moments and their men]. Lisbon: Relógio d'Água.

Goffman, E. (2007). Manicômios, prisões e conventos [Asylums. Essays on the social situation of mental patients and other inmates]. São Paulo: Editora Perspectiva.

Javeau, C. (1998). Lições de sociologia [Sociology lessons]. Oeiras: Celta Editora.

Lima, L. C. (1998). A escola como organização e a participação na organização escolar. Um estudo da Escola Secundária em Portugal (1974-1988) [School as an organisation and participation in school organisation. A study of the Secondary School in Portugal (1974-1988)]. Braga: Centre for Studies in Education and Psychology, Institute of Education and Psychology, University of Minho.

Serpa, S. (2014). O contributo do conceito de instituição total para uma leitura empírica de um contexto educativo. [The contribution of the concept of total institution to an empirical reading of an educational context]. Atas do VIII Congresso Português de Sociologia - 40 anos de democracia(s): progressos, contradições e prospetivas [Proceedings of the VIII Portuguese Congress of Sociology - 40 years of democracy(s): progress, contradictions and prospects]. Lisbon: Portuguese Socliology Association. Retrieved from

http://www.aps.pt/viii_congresso/VIII_ACTAS/VIII_COM0101.pdf

\section{Copyrights}

Copyright for this article is retained by the author(s), with first publication rights granted to the journal.

This is an open-access article distributed under the terms and conditions of the Creative Commons Attribution license which permits unrestricted use, distribution, and reproduction in any medium, provided the original work is properly cited. 